\title{
Stream Network Modelling from Aster GDEM Using ArcHydro GIS: Application to the Upper Moulouya River Basin (Eastern, Morocco)
}

\author{
Khadija Diani' ${ }^{1}$, Hassan Tabyaoui2*, Ilias Kacimi' ${ }^{1}$, Fatima El Hammichi², Chafik Nakhcha ${ }^{3}$ \\ ${ }^{1}$ LO3G Laboratory, Department of Earth Sciences, Faculty of Sciences, Mohammed V-Agdal University, Rabat, Morocco \\ ${ }^{2}$ Natural Ressources and Environnement Laboratory, Polydisciplinary Faculty of Taza, Sidi Mohamed Ben Abdellah University, \\ Fez, Morocco \\ ${ }^{3}$ Polydisciplinary Faculty of Safi, Cadi Ayyad University, Marrakech, Morocco \\ Email: ^hassan.tabyaoui@usmba.ac.ma
}

How to cite this paper: Diani, K., Tabyaoui, H., Kacimi, I., Hammichi, F.E. and Nakhcha, C. (2017) Stream Network Modelling from Aster GDEM Using ArcHydro GIS: Application to the Upper Moulouya River Basin (Eastern, Morocco). Journal of Geoscience and Environment Protection, 5, 1-13.

https://doi.org/10.4236/gep.2017.55001

Received: February 19, 2017

Accepted: May 7, 2017

Published: May 10, 2017

Copyright (c) 2017 by authors and Scientific Research Publishing Inc. This work is licensed under the Creative Commons Attribution International License (CC BY 4.0).

http://creativecommons.org/licenses/by/4.0/

\begin{abstract}
This paper discusses the integration between GIS and hydrological models and presents a case study relating to the upper section of Moulouya River Basin (UMRB) situated in the east of Morocco. The Basin is an inland watershed with a total area of approximately $10,000 \mathrm{~km}^{2}$, stretching in the junction between the Middle Atlas, the High Atlas Mountain and the Middle Moulouya basin. From ArcGIS ArcHydro framework data models, different parameters of the Moulouya River and its catchment area have been defined. DEM based ArcHydro model was run on Aster-GDEM V2 data at a horizontal spatial resolution of 30 meters. Several raster and vector products of the Upper Moulouya River and its catchment area have been defined at the end of the model. Final results of the models were discussed and compared with the reality. These results can be used in baseline for advanced hydrology and geomorphology research on the catchment area. They can support for decisionmaking on ground and surface water resource, distribution and management.
\end{abstract}

\section{Keywords}

Hydrological Modelling, Aster-GDEM V2, ArcHydro, Upper Moulouya Basin, East Morocco

\section{Introduction}

Hydrologic models are simplified, conceptual representations of a part of the hydrologic, or water cycle. They are primarily used for hydrologic prediction and for understanding hydrologic processes. Hydrologic models lay hydrologic 
and topographic parameters. The use of topographic maps for extracting characteristics of the watershed, such as stream network and catchment delineation is essential. This traditional method consists of drawing lines to connecting elevation points and contour lines. This manual delineation of drainage networks and catchments has been widely replaced by the automatic extraction from Digital Elevation Model (DEMs) [1] [2] [3].

Digital elevation models (DEMs) have been frequently used for the morphometric analysis of river basins through the extraction of topographic parameters and stream networks. They have been used in a variety of studies where terrain and drainage factors play prominent roles. Numerous studies on morphometric analysis from DEMs have been carried out across the world in recent years (e.g. [4]-[10]). In Morocco, some of our studies where DEMs have been used for river basin analysis, estimation of soil loss, water resource evaluation and topographic characterization include [11] [12] [13] and [14].

This study estimate elevation profiles, stream networks and morphometric parameters derived from freely available DEM products as well as from topographical maps of different scales for the Upper Moulouya river basin. The different preliminary products were re-sampled to a common resolution $(30 \mathrm{~m})$ for better comparison and analysis, with the results tabulated and integrated in a Geographic information System.

In Geographic Information System, many Hydrologic models are usually integrated for distributed hydrologic simulations [9] [15] [16] [17]. They use algorithms largely discussed in literatures (e.g., [9] [15] [18] [19] [20]). Many GISbased tools have been developed. The "Hydrology" toolset in ArcGIS, developed by Esri [21], has been commonly used for DEM preprocessing and surface stream simulation. WinBasin is a watershed analysis system that can automatically calculate depressionless flow directions, delineate watersheds/sub-watersheds, extract realistic drainage networks, and calculate geomorphologic indices and hydrological responses from DEMs [22]. NRCS GeoHydro is an ArcGIS application that can compute catchments, drainage points, drainage lines, and crosssection details for a storm event hydrologic model [23]. Arc Hydro is ArcGISbased system geared to support application involving water surface resources and groundwater information.

Water erosion and resulting solid transport are the result of the combined action of many factors including geometric, topographic, lithological, soil and anthropogenic factors. All these factors characterize the Upper Moulouya watershed. The objective of this study is to extract, for the first time, the hydrological characteristics of the Upper Moulouya watershed, with a view to future studies of the other factors. The stream network and catchment in the study area will be modelled based on DEMs using Arc Hydro tools.

\section{Data Required and Software Used for the Study}

The major data used for the study was the $30 \mathrm{~m}$ DEM (ASTER-GDEM V2) available for free and downloaded from the NASA server (https://earthdata.nasa.gov/), 
digitalized topographic maps at 1:50,000 scales covering the entire basin. The Aster-GDEM V2 means Advanced Spaceborne Thermal Emission and Reflection Radiometer (ASTER) Global Digital Elevation Model Version 2. This second version released on October 2011 by the METI-Japan and NASA-USA was generated using stereo-pair images collected by the ASTER instrument onboard Terra. The ASTER GDEM V2 is in GeoTIFF format with 30-meter postings and $1 \times 1$ degree tiles. For this study, ArcHydro Add-on/Extension, ArcHydro Groundwater, ArcScene and ArcGIS 9.3 software were used for the analysis [24].

ArcHydro is a hydrologic information system that is a synthesis of geospatial and temporal data supporting hydrologic analysis and modelling [25]. This software provides a compact data structure for storing the most important geospatial data. ArcHydro framework contains geospatial information organized in several levels: geodatabase, feature data set, geometric network, feature class and relationship elements (for more details, see [25]). These levels have the same projection system and spatial reference frame. The feature classes are collections of geometric objects (points, lines, or polygons) that share common themes and attribute types of the watershed of interest.

Preparation of these data is needed before the database can be loaded into the ArcHydro database. We defined the outline of the Upper Moulouya watershed boundary on the basis of topographic information. We first identified the watershed boundaries by manually drawing them onto paper topographic maps. We then compared and correct to delineate watershed on the basis of DEM.

For this study, we used WGS-84 as Geographical coordinate system. All the maps where geo-referenced to Merchich Morocco geographical coordinate system and converted to WGS84 to use and share resulting maps in Google-Earth.

\section{Studied Area}

The Moulouya river, called Marwacht in Berber, is a $600 \mathrm{~km}$-long river in eastern Morocco. Its sources are located in the reliefs of the Middle and High Atlas Mountain. It empties into the Mediterranean Sea in northeast Morocco. The river is used for irrigation and is dammed by five dams (Mohammed V, Machraa Hammadi, Hassan II, Enjil and Arabat). Its watershed is an area of $74,000 \mathrm{~km}^{2}$ and can be divided on three basins: the Upper Moulouya basin, in the south, continues through the basin of the Middle Moulouya. This later continues to the lower Moulouya basin.

The Upper Moulouya basin is an intramontane basin of triangular shape. It is bordered to the west by the Middle Atlas Mountain and to the south by the High Atlas (Figure 1). It forms a basin receiving sedimentary material from the dismantling of the High Atlas and Middle Atlas. The basin covers an area of 9660 $\mathrm{km}^{2}$. Its physiography is dominated by plains (85\%) limited by mountains (15\%). On the plains, the altitudes are less than $2000 \mathrm{~m}$ while on the mountains, they exceed $2000 \mathrm{~m}$.

The climate of the Upper Moulouya is largely influenced by the Atlasic orography. The temperature measured at the stations of Louggagh, Zaida and 


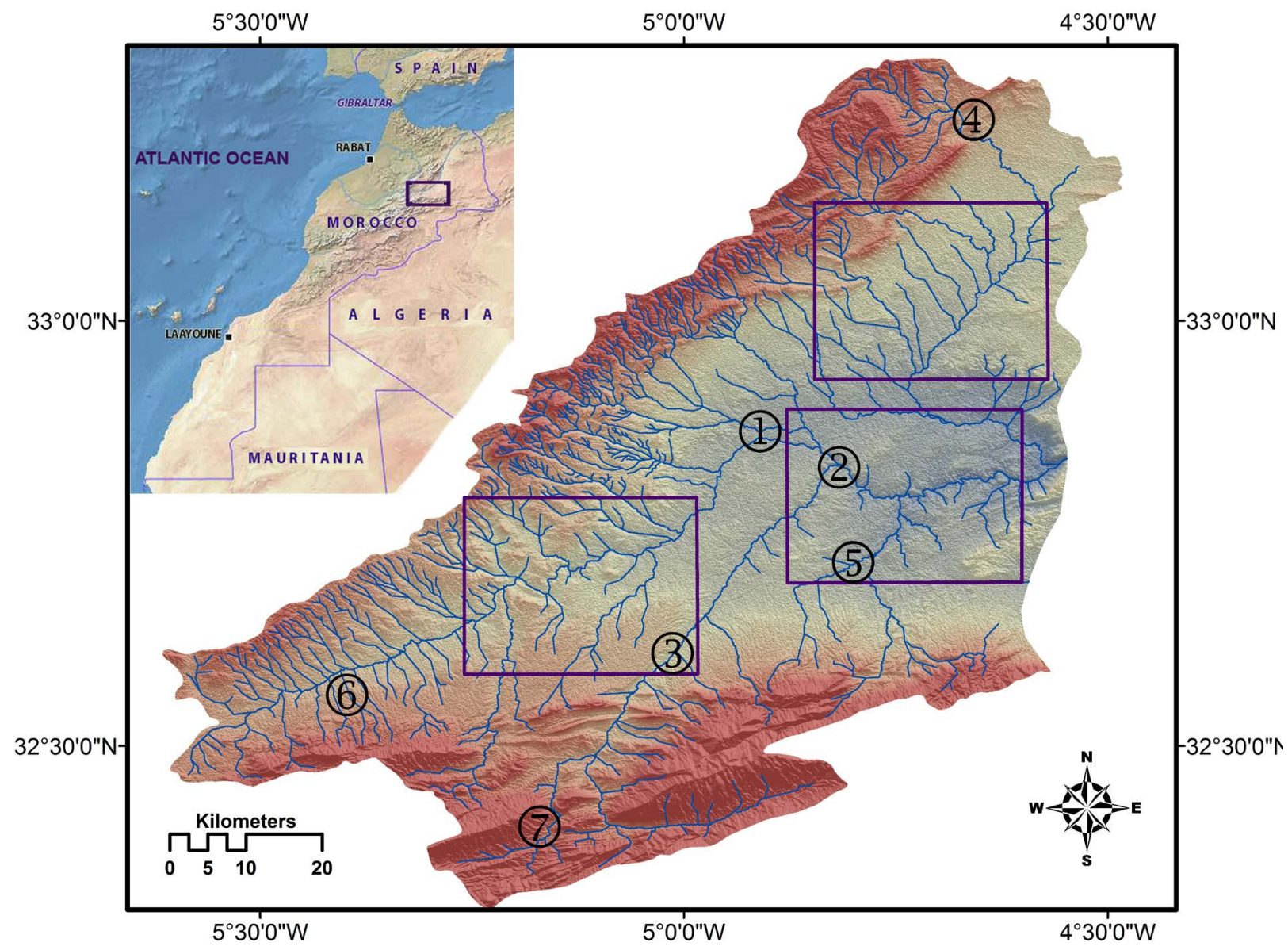

Figure 1. A: Position of Upper Moulouya basin in Morocco, B: DEM obtained after kriging and internal depression filling with drainage lines, all superimposed on hillshades surfaces with direction and Azimuth 45/45 and 315/45 respectively. Boxes indicate position of detailed areas in Figure 5. Number correspond to the climatic stations: 1: Zaida, 2: Ansegmir, 3: Tabouazant, 4: El Aouia, 5: A-Midelt, 6: Louggagh, 7: Anzar Oufounes.

Ansegmir (Figure 1) shows that the annual average is $13^{\circ} \mathrm{C}$ (Figure 2). It is clearly contrasted by a very hot and stormy summer $\left(33.8^{\circ} \mathrm{C}\right.$ in July) and a cold winter $\left(-1.3^{\circ} \mathrm{C}\right.$ in January). It is endowed with a dry continental atmosphere relatively cool when the western winds dominate [26]. The average annual rainfall received over the basin area is about $300 \mathrm{~mm}$. It varies between $210 \mathrm{~mm}$ downstream (Ansegmir station) and rise up to $379 \mathrm{~mm}$ by climbing the Mountainous borders (Oufounes station), with occasional heavy cloud bursts and the area is sometime subjected to snowfall occurring between November and February. Figure 3 shows that the precipitation regime is characterized by two maxima: the highest is in November-December, the second in March on the western border, and in April on the southern edge.

The perimeter of the watershed is about $554 \mathrm{Km}$ and the surface is $9660 \mathrm{Km}^{2}$. The Gravelius compactness index was thus evaluated at $\mathrm{KG}=1.54>1$. The general watershed is therefore rather elongated, which gives an idea of the peak flow: the flood hydrograph is of damped form. Indeed, the rainfall received flows on the surface until the outlet. In the case studied, the arrival time of a shower at a given point is reduced compared to a rounded drainage basin. 


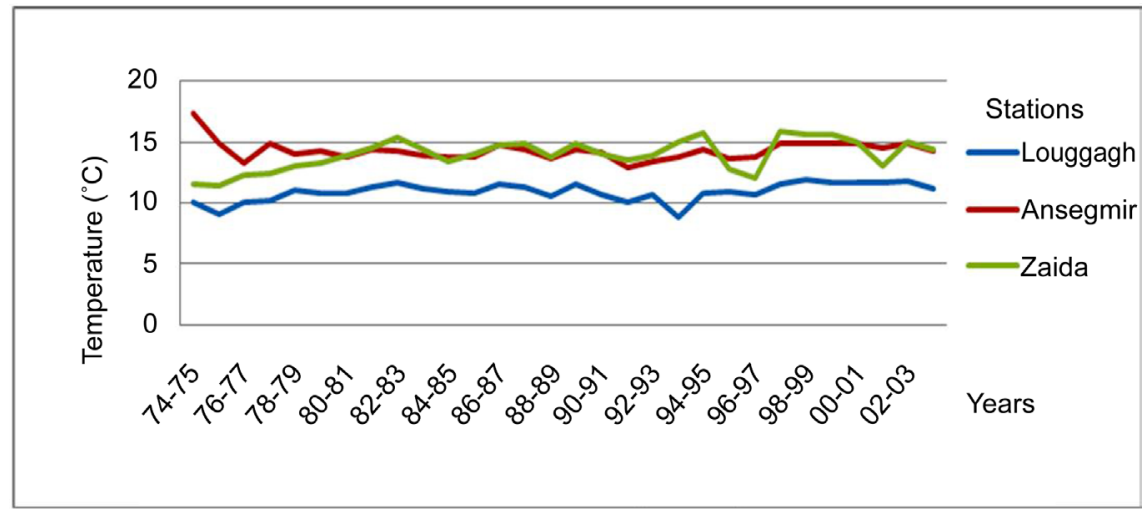

Figure 2. Temperature variation in the Upper Moulouya basin during the last 30 years.

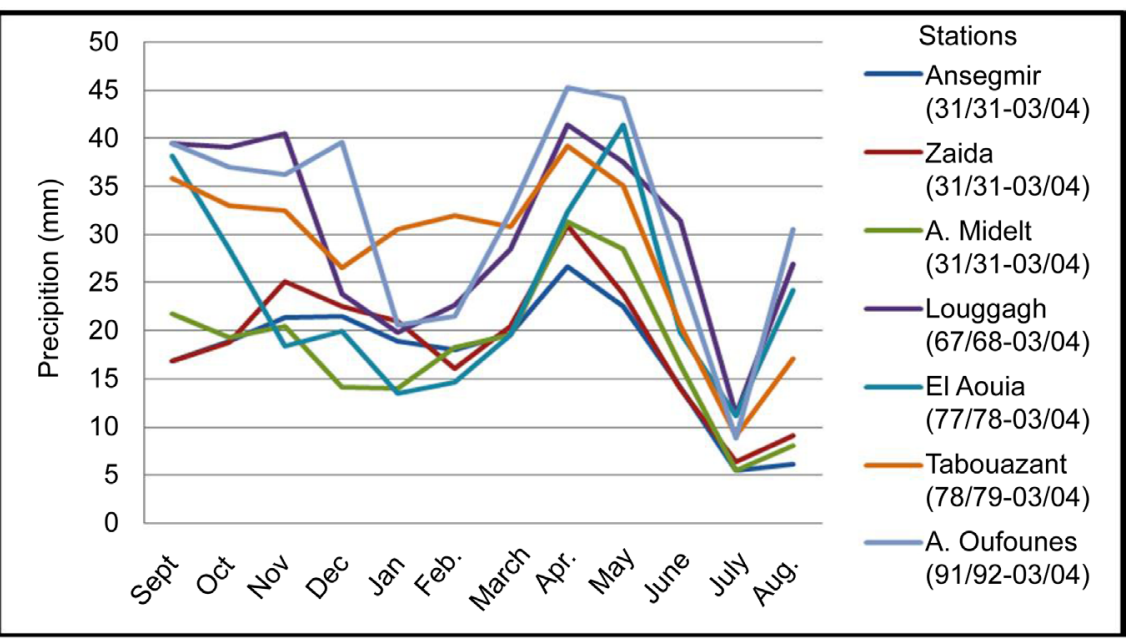

Figure 3. Variation in monthly precipitation recorded at Upper Moulouya basin.

Geologically, the rocks exposed within the basin range from the Palaeozoic to the Quaternary (Figure 4). The Palaeozoic basement is formed by schist and granitic terrains attributed to the Cambro-Ordovician [27]. The schists are metamorphosed and intruded by granitoids of age $330 \pm 2 \mathrm{Ma}$ [28]. The Mesozoic cover rests in very pronounced angular discordance on the palaeozoic [29]. It begins with red detrital clay-salt formations of the Triassic. The Jurassic series is represented by strongly karstified limestones and dolomites [30]. On all this detrital cover, the thicknesses are reduced, especially when approaching the buttonholes, under the action of erosion [31] and also of the fact that these buttonholes remain after the Triassic in a high position [32]. The Cretaceous (Cenomanian) begins with conglomerates with calcareous or sandstone cement, sandstones, clays and marls [33] and continues with Turonian limestones in bars intercalated by beds of clay [34]. The Tertiary is represented by continental Palaeogene deposits (conglomerates, sandstones and marls, and sand dolomites) followed by clayey-conglomerates, lacustrine limestones, marls and gypsums of the Neogene [35]. The Quaternary consists of fluvial terraces and basaltic formations (small cone of projection of Bou Idarne and the cone of Touguejdid to the north of Boumia [32]). 


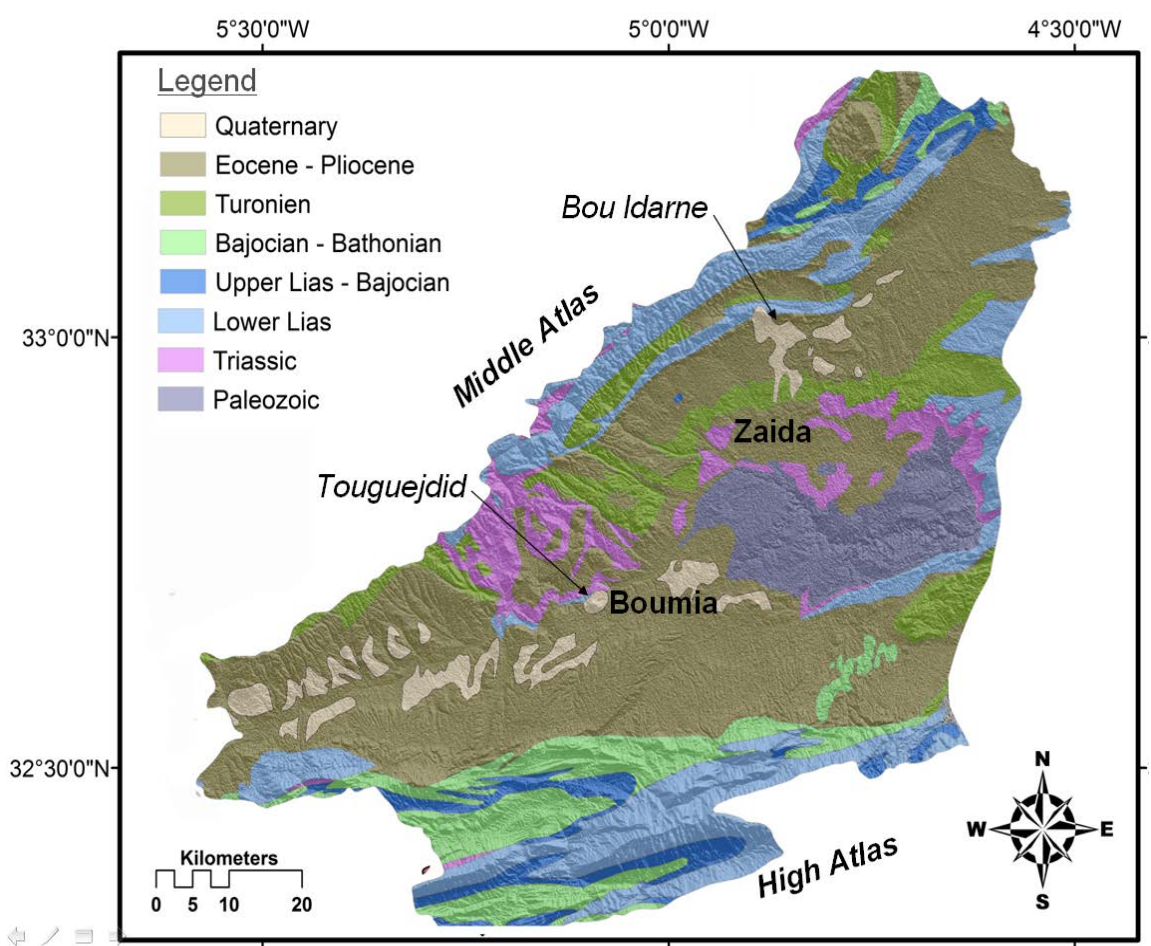

Figure 4. Geological map of Upper Moulouya basin. After the geological map of Morocco at $1 / 1000000$.

\section{ArcHydro Modeling for Watershed Delineation}

The procedure used for watershed delineation in ArcHydro involves a sequence of steps accessed through the toolbar menus. They concern Terrain pre-processing and Watershed processing. For this study, the ArcHydro version 1.4 was utilized. This version is compatible with ArcGIS 9.3.

The first step is a DEM reconditioning. The depressions in the DEM data were firstly 'filled' by increasing the cells value in depression to depression's spill point value. Reconditioning was required to raise the base level of the DEM values to prevent negative values in the DEM and to ensure that flow was not altered by artificial depressions. This step is important when filling sinks in the next step. Sinks are artifact features from DEM creation which are cells in which there is no adjacent downstream cell.

The next process is to compute the flow direction for each cell in the 'filled' DEM of Figure 1. The flow direction algorithm (deterministic eight-node algorithm) [36] [37] was then used to produce the flow direction map. An output raster is created representing the ratio of the maximum altitude change from each cell in the direction of flow over the distance of the path between the center of the cells, expressed as a percentage. The values of $1,2,4,8,16,32,64$, and 128 represents eight possible direction of the flow in each cell. Figure 5 A-B-C shows a screens shot from ArcGIS of the adjusted DEM values focused on three interested areas in the Upper Moulouya watershed.

Flow accumulation network was then created based on the flow direction using the "Flow Accumulation" function. This function computes the flow accu- 
mulation value for each cell. This calculation is important to specify the threshold by which streams are defined in the next step. The raster image thus created shows the drainage lines in classes of different colours. With the "Stream Definition" function, all the cells in the input flow accumulation grid that had a value greater than the given threshold grid was given a value of "1" and defined as stream grid. The stream layer output map is in binary raster format with cells occurring within stream features assigned a value of 1 .

After linking the stream grid using the Stream segmentation function, the stream Link grid map was produced (Figures 5(d)-5(f)). It represents headwater tributaries or segments between confluences, with each segment assigned a unique grid code identifier [38]. Based on this map (the values held by each stream segment), 50 catchments or sub-basins were created using the "Catchment Grid Delineation". These catchment grids were converted to polygon vector features by the "Catchment Polygon Processing" function (Figures 5(d)-5(f)).

Additionally, the stream link grid map from earlier processing, in raster format, was converted to a line feature class (vector format) using the "Drainage line processing" tool. The resulting map shows that channels derived from the DEM are in better agreement with those derived from topographical maps (Figures 5(d)-5(f)). Differences in this respect are particularly marked in the flat portion for small channels, as noted in others works (e.g. [39] [40]).

To facilitate the definition of entry and exit points, the next step generated aggregated adjoint catchment by "Adjoint Catchment Processing” function [41]. The resulting map represents the cumulative upstream area of each stream segment that was not a headwater segment. Finally, drainage points which are point features placed at the transfer points between adjacent catchments were generated using the "Drainage point Processing" (Figures 5(d)-5(f)). 50 points were created. Each point was assigned a unique identifier based on the catchment it drains.

The next steps concern calculation of Longest Flow Path and slop determination. Longest flow path function relies on pre-processed data, and in particular the longest flow path adjoint to speed up the computation of the longest flow paths. This function takes a lot of computing time. The total length of the most important stream is approximately the same to that mapped in topographic map (Moulouya river with $135 \mathrm{~km}$, Ansegmir river with $65 \mathrm{Km}$ ).

We then do some analysis to evaluate the drainage density of each sub-basin of the Upper Moulouya watershed. Drainage density is a fundamental property in Geomorphology because it specifies the scale where there is a transition from hillslope to channel processes. The geodatabase gives a shape area but the units of this are decimal degrees because the spatial reference of this feature class is geographic coordinates. We changed the spatial reference of theses features-class from global geographic coordinates (WGS84) to local one (Merchich Morocco) and then to projected Moroccan coordinate system (Lambert conform conic, zone 2). The attribute Shape Area of Subbasin feature class is then in $\mathrm{m}^{2}$ and may be analysed with drainage Line and longest flow path for each sub-basin. 


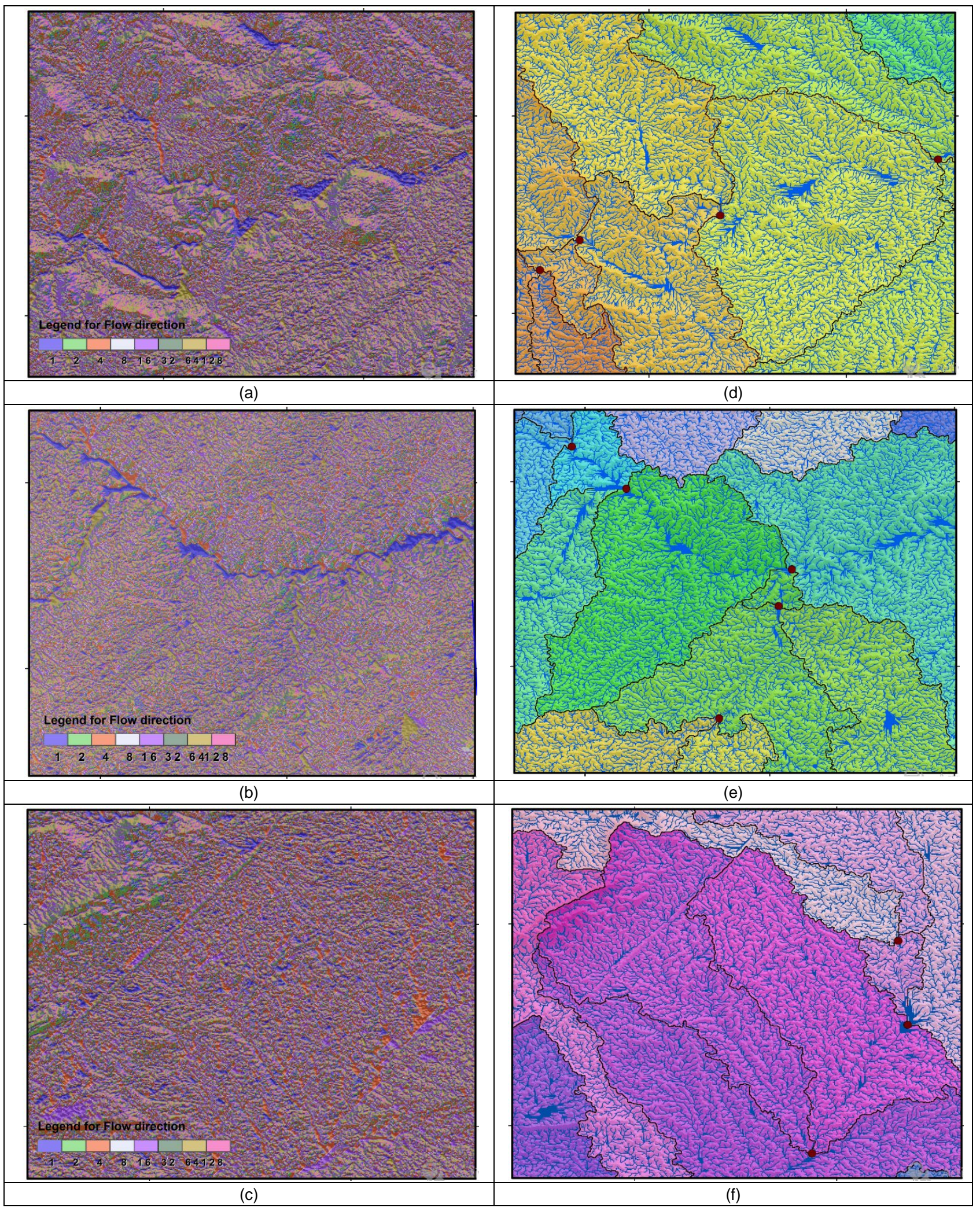

Figure 5. (a)-(c): Associated Flow direction. Flow direction computes each grid's flow direction based on an eight-point pour model, represented by a preselected color. (d)-(f): Channels derived from DEM controlled by drainage derived from topographical maps, limited by catchment. Point placed at the transfer position between adjacent catchments. All maps are displayed with $50 \%$ transparency on hillshades surfaces with direction and Azimuth 45/45 and 315/45 respectively (For location of Portion map, see Figure 1). 


\section{ArcHydro Modeling for Watershed Processing}

Watershed processing functionality permits to delineate watersheds and subwatersheds. Each small catchment has Shape Length and Area attributes. These quantities are automatically computed and become part of a geodatabase. Batch Point Generation creates the Batch Point feature class. The map (Figure 6) shows an outlet points on the flow accumulation path where the flow leaves one sub-basin and enters to another one. The exact position of these points was controlled by topographic map. The batch points are then sufficiently on the drainage lines and the catchment's limits. These files were combined into the batch watershed processing tool, which produced a map showing the up slope area that flows to the outlet location. The Drainage Area Centroid generates the centroid of drainage areas as centers of gravity. Finally Longest Flow Path function identifies and computes the length of the longest flow path in a selected set of drainage areas.

\section{ArcHydro Modeling for Network Extraction}

The Network Tools provide vector network and concern the use of Hydro Network Generation function and Node/Link Schema Generation function. The first process establishes connectivity between the drainage and network feature classes and creates a relationship class between the new HydroJunction feature class and the Catchment feature class that will be used subsequently (Figure 7). The second process allows generating a polyline feature class that provides a connection between the upstream and downstream node. Typically they represent a stream or a channel. The nodes are defined by the centers of the polygons

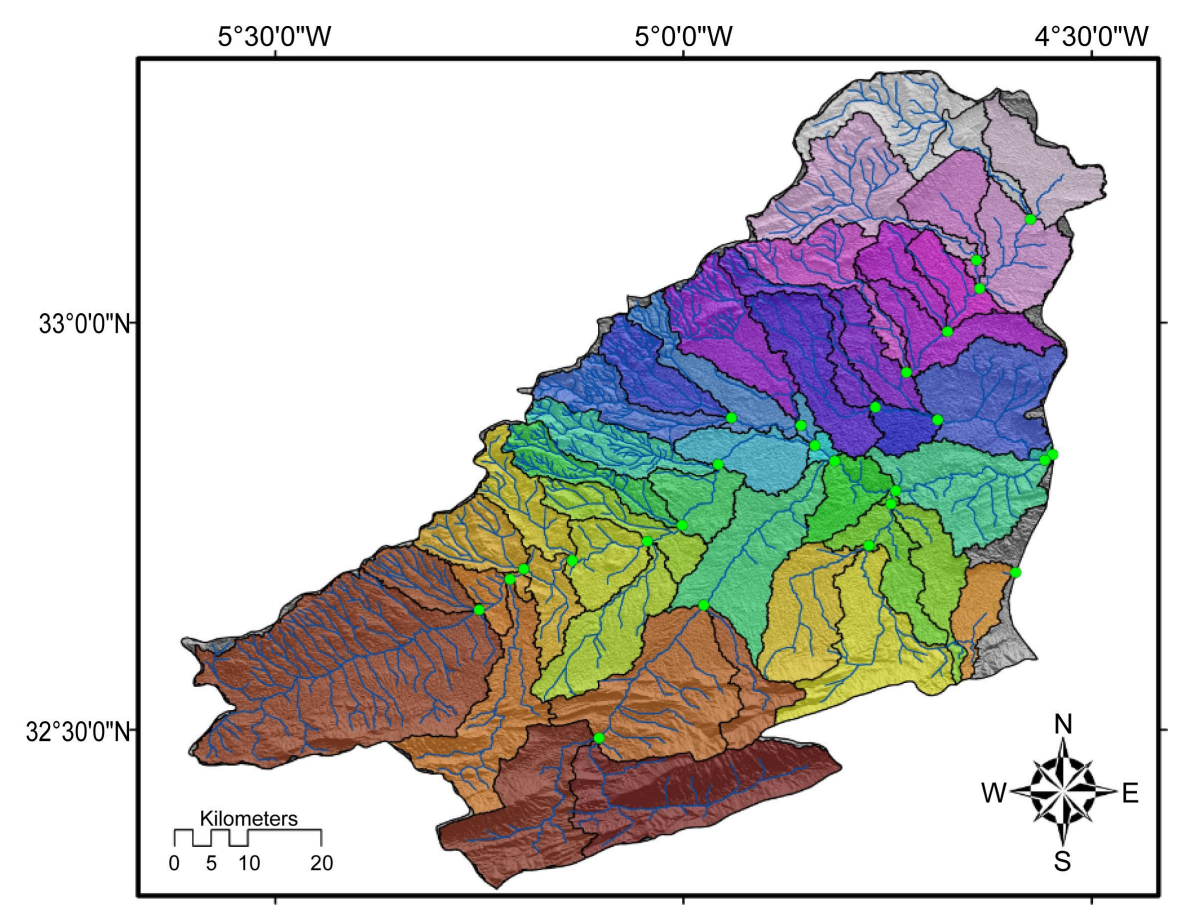

Figure 6. Small catchments and streams with drainage points in the Upper Moulouya ba$\sin$. 


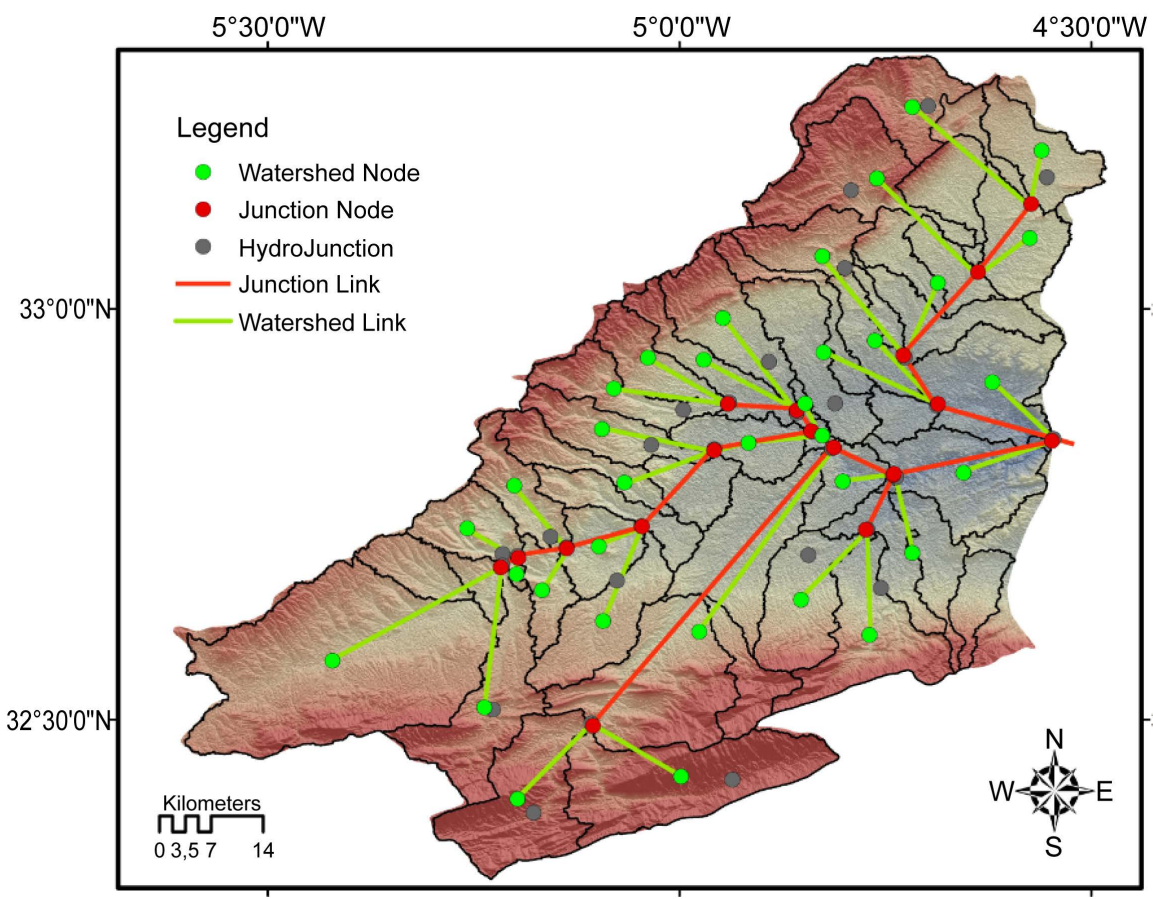

Figure 7. Hydrologic schematic network with basin elements (nodes links, junction/ edges) and their connectivity in the Upper Moulouya basin.

representing basins and by points that represent locations of interest in the model.

\section{Discussion and Conclusions}

Digital Elevation Models (DEMs) have been a subject of increasing attention and utilization in the last few decades because of the relative ease in delineation, extraction and calculation of various drainage and terrain morphometric parameters from them.

The use of ArcHydro with Aster-GDEM V2 in the Upper Moulouya watershed permitted to delineate and characterize the watershed in raster and vector formats, extract and modelling the stream networks. The watershed of the upper Moulouya is drained by a very dense hydrography. Oued Moulouya is the main collector of the basin. It is oriented NE-SW. Drainage is dense on the flanks of the mountains and weak on the plains. The basin is subdivided into two parts, one to the south which contains the tributaries originating from the High Atlas Mountains characterized by a major N-S direction and one to the north, which contains the tributaries originating from the Middle Atlas and generally oriented NW-SE. The study area contains several lines of ridges that allow defining 24 adjoint-catchments, 50 catchments and 50 drainage points.

ArcHydro provides a set of objects and features that can be used as a starting point for many water resource projects. Output data can perform flood forecasting model like HEC-HMS, HEC-RAS and compatible other programs with ArcGIS for rainfall-runoff modelling, and can also be used as a guide for Storm Water Management Model (SWMM). The derived data sets obtained can also 
assist in sediment transport computations and geomorphology research. The results of this study will help to calculate at the sub-catchment scale the soil loss parameters for USLE empirical modelling and soil loss prediction in all types of land in the Upper Moulouya catchment.

Finally, this work is considered as a first version of modelling results in the Upper Moulouya basin, using mainly geospatial data (altimetry, mapping). Future studies will go further, to include climate and hydro-geological parameters and data that complement hydrological and hydrogeological modelling.

\section{References}

[1] Ames, D., Rafn, E., Van Kirk, R. and Crosby, B. (2009) Estimation of Stream Channel Geometry in Idaho Using GIS-Derived Watershed Characteristics. Environmental Modelling \& Software, 24, 444-448.

[2] Jenson, S.K. (1991) Applications of Hydrologic Information Automatically Extracted from Digital Elevation Models. Hydrological Processes, 5, 31-44. https://doi.org/10.1002/hyp.3360050104

[3] Lacroix, M., Martz, L., Kite, G. and Garbrecht, J. (2002) Using Digital Terrain Analysis Modeling Techniques for the Parameterization of a Hydrologic Model. Environmental Modelling \& Software, 17, 125-134.

[4] Moore, I.D., Grayson, R.B. and Ladson, A.R. (1991) Digital Terrain Modelling: A Review of Hydrological, Geomorphological, and Biological Applications. Hydrological Processes, 5, 3-30. https://doi.org/10.1002/hyp.3360050103

[5] Dietrich, W.E., Wilson, C.J., Montgomery, D.R. and McKean, J. (1993) Analysis of Erosion Thresholds, Channel Networks, and Landscape Morphology, Using a Digital Terrain Model. The Journal of Geology, 101, 259-278. https://doi.org/10.1086/648220

[6] Lindsay, J.B. (2005) The Terrain Analysis System: A Tool for Hydro-Geomorphic Applications. Hydrological Processes 19, 1123-1130. https://doi.org/10.1002/hyp.5818

[7] Murphy, P., Ogilvie, J., Meng, F. and Arp, P. (2007) Stream Network Modelling Using Lidar and Photogrammetric Digital Elevation Models: A Comparison and Field Verification. Hydrological Processes, 22, 1747-1754.

https://doi.org/10.1002/hyp.6770

[8] Deng, Y. (2007) New Trends in Digital Terrain Analysis: Landform Definition, Representation and Classification. Progress in Physical Geography, 31, 405-419. https://doi.org/10.1177/0309133307081291

[9] Wu, S., Li, J. and Huang, G. (2008) A Study on DEM-Derived Primary Topographic Attributes for Hydrologic Applications: Sensitivity to Elevation Data Resolution. Applied Geography, 28, 210-223.

[10] Zhang, H. and Huang, G. (2009) Building Channel Networks for Flat Regions in Digital Elevation Models. Hydrological Processes, 23, 2879-2887. https://doi.org/10.1002/hyp.7378

[11] Tabyaoui, H., El Hammichi, F., Er-Rguiouag, M.A. and Lahrach, A. (2011) Hydraulic Modelling Using HEC-RAS and GIS, Application to Oued Inaouen. Taza, Northern Morocco.

[12] Tahiri, M., Tabyaoui, H., El Hammichi, F., Tahiri, A. and El Haddi, H. (2014) Evaluation et Quantification de l'Erosion et la Sédimentation à Partir des Modèles RUSLE, MUSLE et Déposition Intégrés dans un SIG. Application au Sous-Bassin de l'Oued Sania (Bassin de Tahaddart, Rif nord occidental, Maroc). European Journal of Scientific Research, 125, 157-178.

[13] Tahiri, M., Tabyaoui, H., Tahiri, A., El Haddi, H., El Hammichi, F. and Achab, M. 
(2016) Modelling Soil Erosion and Sedimentation in the Oued Haricha Sub-Basin (Tahaddart Watershed, Western Rif, Morocco): Risk Assessment. Journal of Geoscience and Environment Protection, 4, 107-119.

https://doi.org/10.4236/gep.2016.41013

[14] Deffontaines, B., Tabyaoui, H., El Hammichi, F., Chaouni, A., Mounadel, A., Lahsaini, M., Magalhaes, S. and Fortunato, G. (2015) Importance of Geological Map Updates in Engineering Geology, Application to the Rif-Chain and Its Foreland (Northern Morocco). Engineering Geology for Society and Territory, 6, 101-105.

[15] Fairfield, J. and Leymarie, P. (1991) Drainage Networks from Grid Digital Elevation Models. Water Resources Research, 27, 709-717.

https://doi.org/10.1029/90WR02658

[16] Konadu, D. and Fosu, C. (2009) Digital Elevation Models and GIS for Watershed Modelling and Flood Prediction-A Case Study of Accra Ghana. In: Yanful, E.K., Ed., Appropriate Technologies for Environmental Protection in the Developing World, Springer, Berlin, 325-332. https://doi.org/10.1007/978-1-4020-9139-1_31

[17] Moharana, P. and Kar, A. (2002) Watershed Simulation in a Sandy Terrain of the Thar Desert Using GIS. Journal of Arid Environments, 51, 489-500.

[18] Jones, R. (2002) Algorithms for Using a DEM for Mapping Catchment Areas of Stream Sediment Samples. Computers \& Geosciences, 28, 1051-1060.

[19] Turcotte, R., Fortin, J., Rousseau, A., Massicotte, S. and Villeneuve, J. (2001) Determination of the Drainage Structure of a Watershed Using a Digital Elevation Model and a Digital River and Lake Network. Journal of Hydrology, 240, 225-242.

[20] Zhang, H., Huang, G.H. and Wang, D. (2013) Establishment of Channel Networks in a Digital Elevation Model of the Prairie Region through Hydrological Correction and Geomorphological Assessment. Canadian Water Resources Journal, 38, 12-23. https://doi.org/10.1080/07011784.2013.773788

[21] Esri (2004) Arc Hydro Tools Overview. ESRI, USA.

[22] Lin, W.T., Chou, W.C., Lin, C.Y., Huang, P.H. and Tsai, J.S. (2008) WinBasin: Using Improved Algorithms and the GIS Technique for Automated Watershed Modelling Analysis from Digital Elevation Models. International Journal of Geographical Information Science, 22, 47-69. https://doi.org/10.1080/13658810701300121

[23] Merkel, W., Kaushika, R. and Gorman, E. (2008) NRCS GeoHydro-A GIS Interface for Hydrologic Modeling. Computers \& Geosciences, 34, 918-930.

[24] ESRI (2008) ESRI ArcMap 9.3. Redlands, USA.

[25] Maidment, D. (2002) ArcHydro GIS for Water Resources. ESRI Press, Redlands, CA.

[26] Combe, M. and Simonot, M. (1971) Ressources en eaux du Maroc : La haute moulouya, le sillon d'Itzer-Enjil et le massif de Bou-Mia-Aouli. Notes et Mémoires Service Géologique du Maroc, 231, 193-201.

[27] Hoepffner, C. (1987) La tectonique hercynienne dans l'Est du Maroc. Thèse ès Sciences, Université de Strasbourg, $280 \mathrm{p}$.

[28] Oukemeni, D., Bourne, J. and Krogh, T.E. (1995) Géochronologie U-Pb sur Zircon du Pluton d'Aouli. Haute Moulouya. Maroc. Bulletin de la Societe Geologique de France, 166, 15-22.

[29] Emberger, A. (1965) Carte polygénétique des minéralisations plombifères de la Haute Moulouya (gisements d'Aouli, Mibladen et Zeïda), Maroc. Comptes Rendus de 1 Académie des Sciences, 160, 3433-3436.

[30] Dagallier, G. and Macaudiere, J. (1987) Contrôles tectoniques des concentrations $\mathrm{Pb}-\mathrm{Ba}$ en milieu carbonaté de Mibladen (Maroc). Bulletin de la Societe Geologique de France, 8, 387-394.

[31] Jaouani, L. (2001) Etude géologique et gitologique des gisements plombifères de la boutonnière d'Aouli (Aouli, Zeida, Mibladen) Haute Moulouya (MAROC). Thèse en géologie appliquée, Université Mohammed V Rabat, 252 p. 
[32] Schmitt, J.M. (1976) Sédimentation, paléoaltération, géochimie et minéralisation en plomb de la série triasique de Zeida (Haute Moulouya, Maroc). Thèse en sciences et techniques minières, Ecole nationale supérieure de Paris, $110 \mathrm{p}$.

[33] Felenc, R. and Lenoble, J.P. (1965) Les gîtes de plomb de Mibladène. Notes et Mémoires Service Géologique du Maroc, 181, 186-196.

[34] Derrar, N. (1996) Synthèse géologique et hydrologique de la Haute et la Moyenne Moulouya (Maroc). Mémoire de fin d'étude, Ecole Nationale de l'Industrie Minérale, Rabat, Maroc, 169 p.

[35] Naji, M. (2004) Les minéralisations plombo-barytiques du district de la Haute Moulouya: Contexte géologique, contrôle tectonique et modèle de mise en placeGisements d'Aouli-Mibladène, Maroc. Thèse en géologie appliquée, Université Mohammed V, Rabat, 218 p.

[36] O'Callaghan, J.F. and Mark, D.M. (1984) The Extraction of Drainage Networks from Digital Elevation Data. Computer Vision, Graphics and Image Processing, 28, 323-344.

[37] Hornberger, G.M. and Boyer, E.W. (1995) Recent Advances in Watershed Modelling. Reviews of Geophysics, 33, 949-957. https://doi.org/10.1029/95rg00288

[38] Oliveira, F., Furnans, J., Maidment, D., Djokic, D. and Ye, Z. (2000) Drainage Systems. In: Maidment, D.R., Ed., Arc Hydro: GIS for Water Resources, ESRI Press, Redlands, 55-86.

[39] Mizgalewicz, P.J. and Maidment, D.R. (1996) Modeling Agrichemical Transport in Midwest Rivers Using Geographic Information Systems. Center for Research in Water Resources Online Report 96-6, University of Texas, Austin, TX.

[40] Moore, I.D. (1996) Hydrologic Modeling and GIS. In: Goodchild, M.F., Steyaert, L.T., Parks, B.O., Johnston, C., Maidment, D.R., Crane, M.P. and Glendinning, S., Eds., GIS and Environmental Modeling: Progress and Research Issues, GIS World Books, Fort Collins, 143-148.

[41] Diani, K. (2013) Modélisation spatiale des données hydrologiques et hydrogéologiques du bassin de la Haute Moulouya, Application de Geodatabase, d'Arc Hydro et d'ArcHydro Groundwater. Mémoire de Fin d'études de Master Sciences et Techniques, FST-Fès, 58 p.

Submit or recommend next manuscript to SCIRP and we will provide best service for you:

Accepting pre-submission inquiries through Email, Facebook, LinkedIn, Twitter, etc. A wide selection of journals (inclusive of 9 subjects, more than 200 journals)

Providing 24-hour high-quality service

User-friendly online submission system

Fair and swift peer-review system

Efficient typesetting and proofreading procedure

Display of the result of downloads and visits, as well as the number of cited articles

Maximum dissemination of your research work

Submit your manuscript at: http://papersubmission.scirp.org/

Or contact gep@scirp.org 